\title{
Interaction of Wildlife and People Residing near National Park Area
}

\author{
Devendra Dhakal, Associate Professor
}

Birendra Multiple Campus, Chitwan

\begin{abstract}
Interaction is the relationship between organisms for food, shelter and other needs. It may be positive or negative. There is strong interaction between wildlife and local people particularly at the national park and its adjoining area. Local people are responsible for a number of problems related to protected area management. The objective of this study was to assess the causes of interactions and find out the ways for park-people management. This study has been designed to reveal the intricate relationship among the wildlife and local people. The study applied cross-sectional design and used quantitative and qualitative approaches to collect data. Research instruments namely interview, questionnaire and observation were applied for this study. In any National Park in Nepalese context relation between wildlife and local people is positive and negative. Wildlife helps in promoting and maintaining greenery. It also helps in promoting tourism in the area.
\end{abstract}

\section{KEY WORDS}

Interaction, Conflict, Wildlife, Local People, National Park

\section{INTRODUCTION}

Interaction takes place between different animals to sustain life. It is a common phenomenon in protected areas where animals are protected for their growth and development. Interaction of wildlife and people takes place for a niche. Niche is an organism's habitat or a location. It is an organism's pattern of use of its habitat. Interactions between species are categorized at the level where one population interacts with another. The five major types of species interactions are competition, predation, parasitism, mutualism, and commensalism. These categories are based on whether each species causes benefit or harm to the other species in a given relationship. Conflict is a negative interaction which takes place between different animals involving humans too.

Interaction of wildlife and local people may be both positive and negative. Local people are getting a lot of benefits through the animals, but at the same time they are also affected by the destruction of their crops by wildlife. Negative interaction or conflict takes place due to the competition between the park and people (Bisong, 2009). Crop damage, livestock loss and local harassment by rhino, deer, boars, parakeets, tiger and leopard may be the main problem. Because 
of wildlife, protected areas are established which attract tourists which in turn help in creating employment and raising economic growth.

\section{OBJECTIVES}

The objectives of this study were as follows:

- to identify the factors of interaction between wildlife and local people,

- to assess the role of local people in safeguarding wildlife and

- $\quad$ to study the causes and impacts of interactions of park-people management.

\section{AREA OF THE RESEARCH}

He study was carried out in Chitwan National Park which lies in the lowlands or inner terai of southern central Nepal. It covers an area of $932 \mathrm{~km}^{2}$ of subtropical forest which is dominated by sal trees (Shorea robusta) occupying $60 \%$ of the total area. The park has 503 endangered great one-horned Asian rhinoceros, 120 Royal Bengal tiger and 40-50 elephant (CNPO, 2013).

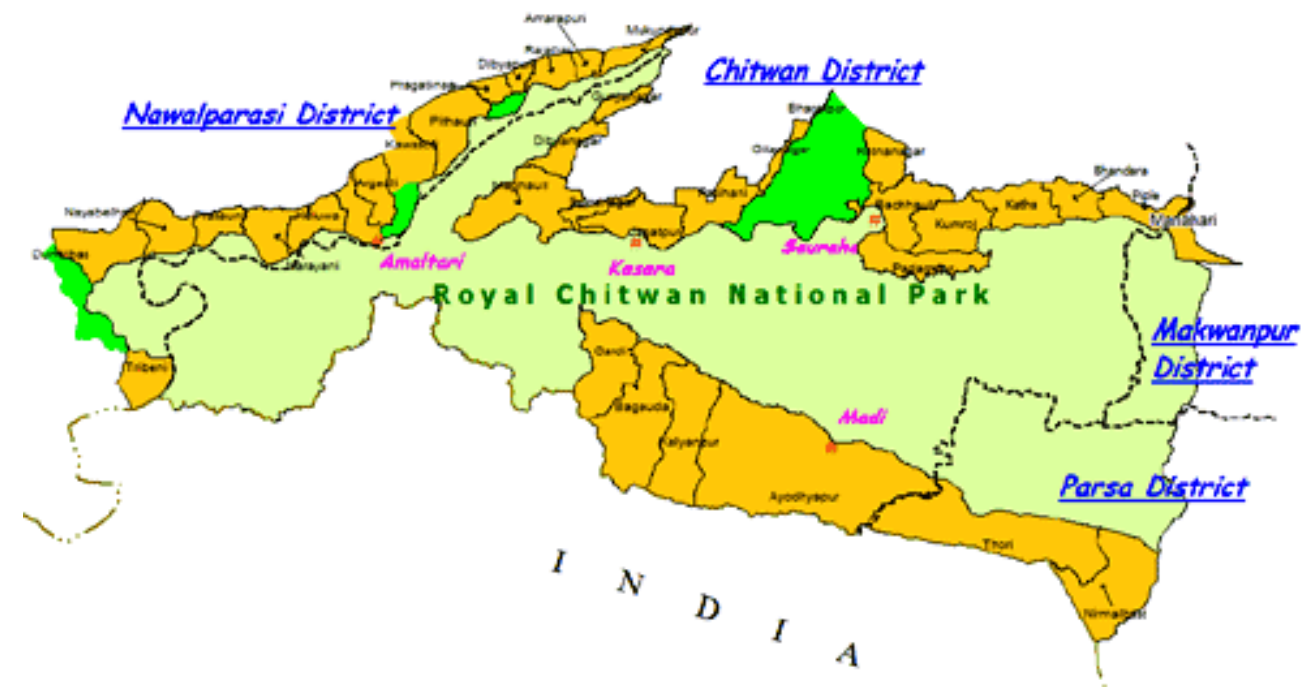

Fig. 1. Chitwan National Park and its Boundary

\section{METHODOLOGY}

The study was based on the review of various literatures relevant to the interaction of wildlife and local people. From these documents, information such as types and extent of conflict, role of local authorities etc. were gathered. The study also followed cross-sectional design contacted local people through interview and questionnaires to collect data. Both the quantitative and qualitative data were collected. Research instruments namely questionnaire, observation and interview were applied for this study. 


\section{RESULTS AND DISCUSSION}

Local people particularly indigenous communities have made significant contributions to the utilization and conservation of the world's ecosystems. Human settlements around and within protected areas are often detrimental to the cause of wild-life conservation (Usher, 1986). This is attributed to the fact that the presence of any conservation effort often robs the indigenous people of the vital resources on which their existence depend upon.

Local people are responsible for a number of problems related to protected area management. Their role is also detrimental to the animals residing in the forest. The protected areas face various land use and management problems such as deforestation, wildlife poaching, illicit loggings, uncontrolled bush fires, shifting cultivation and over-grazing. The reason is not farfetched as the land environment is faced with dense population pressures, inequality and access to natural resources (Larsson, 2001).

Wildlife in many protected areas is under threat from human encroachment, poaching for commercial or subsistence purposes, habitat degradation, encroachment of incompatible land uses, loss of migration and dispersal areas, and ever increasing human-wildlife conflicts (Yukon, 2013). In a scenario where wildlife-induced damages to human property and life are neither controlled nor compensated, negative local attitudes towards conservation and wildlife resources become entrenched.

People living near the forest or protected area considers wildlife a cause for the loss of their crops and other properties. They also report destruction caused by wildlife and ask for compensation from the government. The most frequent problems are not caused by large animals but by insects, whose effects on humans and human installations range from mere aggravation (eg. mosquitoes and black flies) to possible death for certain park visitors (eg. from wasp and bee stings).

It is clear that there is no single approach that will guarantee the coexistence of large carnivores with people throughout Africa or elsewhere. Circumstances vary, and thus so must solutions: there is variation in habitats, availability of prey, patterns of land-use and animal husbandry, and people's attitudes towards large carnivores.

In the past wildlife were persecuted ruthlessly in the name of hunting, the hunters themselves started the protection measures. Wildlife was supposed to have no value, so treated only as the object for pleasure. Ruthless killing as well as initiating protecting measures were more during the premiership of Jung Bahadur Rana in 1846 (Upreti, 1991). The first legislation to protect the country's wildlife was introduced during the Rana regime about 150 years ago. National Conservation Strategy (1988) stressed on environment friendly approach while undertaking 
development activities and sustainable use of the natural resources. Protected areas were initially established for the protection of wildlife especially endangered ones (Shrestha, 2006).

The incidents of animal poaching and destruction of park resources and infrastructure, indicate that people still do not feel "ownership" of the park systems and remain indifferent during the crisis time. So far, government has been only sharing benefits but not responsibilities, and has thus encouraged communities to be mere passive beneficiaries. Promotion of community based natural resources management programme in the buffer zone had also served as an added habitat for wildlife and important forestry resource base for the communities. The values attached to conservation by a society often depend on moral and ethical factors such as interest in the survival and welfare of the present resource status and the willingness to protect these resources for the future. This will to a large extent determine the willingness to conserve such resources (Timsina, 2015).

\section{CONCLUSION}

Establishment of protected areas, like national parks, has traditionally been recognized as the single most important method for securing conservation of terrestrial animal species. In many developing countries, this practice dates back to the colonial era, and the objective has always been to protect wild animals and natural habitats through strongly restricted wildlife utilization (Skonhoft, 2006).

Time has come to realize the ever increasing role of wildlife in protecting local environment and safeguarding the survival of human. Local people should realize this intricate relationship between wildlife and themselves and forcefully act on protecting the wildlife in their area. They should realize that the area they inhabit was once the roaming place of wildlife (WWF, 2005). Because of this truth, local people should abide by the rules and regulations promulgated by the government and made by the local community also. Similarly, government should also understand the intricacy of the life of local people which fully depend on the use of local natural resources and give them special prerogative to the local people so that they can harmoniously live in their own area.

\section{Bibliography}

Bisong, E. A. (2009). Conflicts, Conservation and Natural Resource use in Protected Area Systems: An Analysis of Recurrent Issues. European Journal of Scientific Research.

Skonhoft, A. (2006). Economic modeling approaches for wildlife and species conservation. Ecological Economics , 223-231. 
ISSN: 2362-1303 (Paper) | eISSN: 2362-1311(Online)

JOURNAL OF ADVANCED ACADEMIC RESEARCH (JAAR)

October 2016

Timsina, T. P. (2015). Conflict of Local People and Larger Mammals - A Case of Chitwan National Park in Central Nepal. JAAR.

Upreti, B. N. (1991). Status of National Parks and Protected Areas in Nepal. Italy: Food and Agriculture Organization.

Usher, M. B. (1986). Wildlife conservation evaluation: attributes, criteria and values. London, New York.: Chapman and Hall.

WWF. (2005). Human Wildlife Conflict Manual. Harare: World Wide Fund for Nature .

Yukon, G. o. (2013). Human-Wildlife Conflict. Canada: Government of Yukon. 